\title{
Matching Subjective Assessments of Sod Strength to Quantitative Measurements of Peak Shear Force with Predominately Kentucky Bluegrass Sod
}

\author{
Karl Guillard ${ }^{\mathbf{1}}$ and Richard J.M. Fitzpatrick \\ Department of Plant Science and Landscape Architecture, University of \\ Connecticut, 1376 Storrs Road, Unit 4067, Storrs, CT 06269-4067
}

\author{
Holly Burdett \\ Department of Fisheries, Animal \& Veterinary Sciences, University of Rhode \\ Island Cooperative Extension, 120 Flagg Road, CBLS Rm 383, Kingston, RI \\ 02881
}

Additional index words. Poa pratensis, shear strength, sod quality, turfgrass quality

\begin{abstract}
Adequate turfgrass sod strength for harvesting and handling is typically determined by the producer's past experience and subjective appraisal. This study was conducted to determine the relationship between producer subjective sod-strength assessments and quantitative shear-strength measurements with predominantly kentucky bluegrass (Poa pratensis L.) turf. Across three consecutive growing seasons, 93 samples were collected from sod fields in Rhode Island and assessed for sod strength by subjective and quantitative methods. Producer subjective ratings of sod strength were significantly $(P<0.0001)$ associated with quantitative measurements of peak force required to shear a sod strip. Minimally acceptable strength occurred most frequently when peak shear force was between 55 and $85 \mathrm{~kg} \cdot \mathrm{m}^{-1}$ width of sod; whereas preferred sod strength occurred most frequently when peak shear force was between 70 and 140 $\mathrm{kg} \cdot \mathrm{m}^{-1}$ width of sod. Once peak force exceeded 58 and $86 \mathrm{~kg} \cdot \mathrm{m}^{-1}$, there was a $>50 \%$ probability that sod strength would be judged at least adequate and at preferred strength, respectively, up to a peak force of $140 \mathrm{~kg} \cdot \mathrm{m}^{-1}$. The results suggest that quantitative measurements of shear strength can be related to producer subjective assessments, and provide unbiased benchmark values to guide management decisions for kentucky bluegrass sod production.
\end{abstract}

Quantitative measurement of sod strength has been reported previously in the literature and is typically related to the force required to shear a strip of sod into two separate pieces. Several devices have been designed to quantitatively measure sod shear strength (Burns and Futral, 1980; Goatley et al., 1997; Parish, 1995; Rieke et al., 1968; Sharpe et al., 1989; Shildrick, 1982; Sorochan and Rogers, 2000). These devices, or modifications based on them, have constituted the majority of

\footnotetext{
Received for publication 12 Mar. 2015. Accepted for publication 7 July 2015.

We thank the cooperating Rhode Island sod producers in this study. Funding for this project was provided by the University of Rhode Island Cooperative Extension Water Quality Program through Rhode Island NRCS Grant Agreement Number 68-1535-09-02A, and from Rhode Island NRCS CIG Program Grant Agreement Number 69-1535-10-02. We appreciate the comments of Jason Henderson, Steven Rackliffe, Michael Sullivan, and the anonymous reviewers during the preparation of the manuscript.

${ }^{1}$ Corresponding author. E-mail: karl.guillard@uconn. edu.
}

studies where sod strength has been reported (e.g., Agnew and Christians, 1992; Cutulle et al., 2013; Giese et al., 1997; Hall, 1980; Hall et al., 1985; Hall and Bingham, 1993; Hurley and Skogley, 1975; Li et al., 2011; McCalla et al., 2008; Rieke and Beard, 1969; Ruemmele et al., 2001; Shearman et al., 2001; Taylor and Schmidt, 1980).

Although a quantitative measurement of sod strength can be made and related to specific treatment effects (e.g., $\mathrm{N}$ rate, growth regulators, species, and cultivar comparisons, etc.), there is limited information as to what constitutes an acceptable to preferred value or range of sod strength measurements. Before shearstrength assessment can become a routine tool for sod management, benchmark values need to be established for these devices that indicate when sod is at or within an acceptable to optimum shear strength range for harvesting and handling. Once these values or ranges are established, producers may be more willing to consider devices that quantitatively measure sod strength, and use them to guide their management practices in achieving the optimum strength of sod at harvest. In addition, having an objective measure of shear strength would give a higher degree of criteria on judging acceptability to meet a contract or to resolve contract disputes about sod quality.

The objective of this research was to determine if any relationship exists between subjective producer assessment of sod strength and quantitative measurements of strength obtained from a device that records peak shear force. If a relationship could be obtained, then a further objective was to establish ranges of quantitative measurements that matched producer subjective assessments of acceptable to preferred sod strength for harvesting and handling.

\section{Materials and Methods}

Sod strips were harvested from production fields in West Kingston, RI, across three consecutive growing seasons (2010-12). Within each field in each year, samples were collected at different locations that received varying $\mathrm{N}$ rates. It was anticipated that a wide range of sod strengths would be obtained across the different fields and fertility practices. During all three growing seasons, fields were mowed on a regular basis by the producer with clippings returned. Producers applied supplemental irrigation, as well as pest control measures on an as-needed basis.

In 2010, the soil at the sod farm was a Walpole sandy loam (sandy, mixed, mesic Aeric Endoaquepts). The field was seeded in Sept. 2009 with $75 \%$ kentucky bluegrass and $25 \%$ fine fescues [equal proportions of creeping red (Festuca rubra L. subsp. rubra) and hard fescue (Festuca brevipila Tracey)]. On 13 Oct. and again on 3 Nov., a total of 32 sod strips $(0.46-\mathrm{m}$ wide by $1.83-\mathrm{m}$ long, cut to a 10 - to $20-\mathrm{mm}$ thickness) were harvested from various locations in the field using the producer sod harvesting equipment. Three random sod strips were collected in each location (one location had two strips), and subjectively evaluated by two field managers with at least 20 years of experience for sod strength using the following ordinal rating scale: 1) "Unacceptable-Too Weak" - excessive tearing at harvest or handling and not salable; sod falls apart; 2) "Adequate" — minimally acceptable for harvesting and handling, but not preferred; some tearing could occur when handled; 3) "Preferred"-minimal harvesting and handling losses; and 4) "UnacceptableToo Mature" - not desirable because of excessive thatch and overly mature. After subjective assessment, each sod strip was tested for shear strength using a device similar to that described by Sorochan and Rogers (2000) with a digital load cell that measured peak force (kg) to shear (Chatillion Model DFE-200, Ametek TCI Division, Largo, FL). In 2010, an additional sod strip was harvested and rated at a different field with 2-year-old kentucky bluegrass sod.

In 2011, the sod was located on an Enfield silt loam soil (coarse-silty over sandy or sandy-skeletal, mixed, active, mesic Typic Dystrudepts). This field was seeded in Sept. 2010 with $100 \%$ kentucky bluegrass. On 19 July 2011, three random strips (0.61-m wide 
by $1.52-\mathrm{m}$ long, cut to a thickness of 10 to 20 $\mathrm{mm}$ ) were taken at various locations in the field for a total of 30 samples, rated by the same two field managers from 2010, and measured for peak shear force as described in 2010 .

In 2012, the sod field soil consisted of an Enfield silt loam (coarse-silty over sandy or sandy-skeletal, mixed, active, mesic Typic Dystrudepts) and a Hinckley gravelly sandy loam (Sandy skeletal, mixed, mesic Typic Udorthents). This field was seeded in Sept. 2011 with 70\% kentucky bluegrass and 30\% fine fescues, containing equal proportions of creeping red, hard, and Chewings $[F$. rubra L. ssp. fallax (Thuill.) Nyman]. On 20 Sept. 2012, three random strips $(0.61-\mathrm{m}$ wide by 1.52-m long, cut to a thickness of 10 to 20 $\mathrm{mm}$ ) were taken from various locations in the field (total of 30 samples), rated by two different field managers than those between 2010 and 2011 (with at least 10 years of experience), and measured for peak shear force as described in 2010.

Because the widths of the sod harvesters were not the same in different years, sod peak shear force values were expressed on a per meter width basis (dividing peak shear values by the harvest widths: $0.46 \mathrm{~m}$ in 2010 , and by $0.61 \mathrm{~m}$ in 2011 and 2012). Values were separated into peak shear force $(\mathrm{kg})$ per meter width categories $(<55,55$ to $<70,70$ to $<85$, 85 to $<100,100$ to $<115,115$ to $<140$, and $\geq 140$ ) and used to construct a contingency table with producer subjective sod strength ratings ("Unacceptable-Too Weak," "Adequate," "Preferred," and "Unacceptable-Too Mature") (total $n=93$ ). The frequency of observations was indicated for each cell combination of peak shear force category and producer subjective rating category ( 28 total cells). A test of linear correlation of ordinal data between the producer subjective sod strength ratings and peak shear force categories was conducted by using the Cochran-MantelHaenszel $\chi^{2}$ test, in addition to a log likelihood ratio $\chi^{2}$ test of association (because some of the cell frequencies were $<5$ ). The FREQ procedure in the Statistical Analysis Software (SAS) package (Version 9.4; SAS Institute Inc., Cary, NC) was used for each analysis.

Logistic curves of binary responses for the probabilities of producer-rated acceptable and preferred sod strength vs. unacceptable and not preferred, respectively, as a function of shear-strength measurements were determined with a linear logistic model $(a+b x=$ $\{\ln [\pi /(1-\pi)]\})$ using the LOGISTIC procedure of SAS (version 9.4) on 92 matched-pairs of data. In this model, $\pi$ is the probability of peak shear force being at least "Adequate" (which included the producer-rated "Adequate" and "Preferred" strength categories) as a function of peak shear force. A separate model was run to determine the probability of peak shear force of being "Preferred" as a function of peak shear force. The single datum for the "Unacceptable-Too Mature" category was not included in either logistic regression. Both models passed the Hosmer-Lemeshow goodness-of-fit test $(P>0.05)$, indicating a good fit of the data to the model.

\section{Results and Discussion}

Producer-subjective ratings of sod strength were significantly $(P<0.0001)$ related or associated with quantitative peak shear force measurements expressed per meter of sod width (Table 1). The Cochran-Mantel-Haenszel $\chi^{2}$ test indicated a linear correlation between the ordinal producer-subjective ratings and quantitative peak shear force measurements. This was supported by the log likelihood ratio $\chi^{2}$ test that indicated that producer ratings were associated with the quantitative peak shear force measurements, and not randomly observed across peak shear force categories. Higher peak shear force values were more likely associated with producer ratings of "Adequate" and "Preferred" than for ratings of "Unacceptable-Too Weak." At the thickness of sod harvested on the fields in this study (10 to $20 \mathrm{~mm})$, a peak shear force value between 55 and $85 \mathrm{~kg} \cdot \mathrm{m}^{-1}$ width of sod, with the device we used, was most frequently associated with minimally acceptable strength of sod ("Adequate") for harvesting and handling (Table 1). Once peak force exceeded 58 and up to $85 \mathrm{~kg} \cdot \mathrm{m}^{-1}$ width of sod, there was a greater than $50 \%$ to $97 \%$ chance of obtaining at least an acceptable sod strength rating (Fig. 1; Table 2). At a peak shear force of $140 \mathrm{~kg} \cdot \mathrm{m}^{-1}$ width of sod, it was virtually certain that strength would be deemed at least acceptable by the producers.

Peak shear force values between 70 and $140 \mathrm{~kg} \cdot \mathrm{m}^{-1}$ width of sod resulted in the greatest proportion of 'Preferred' ratings by the producer (Table 1). Once peak force exceeded 86 and up to $140 \mathrm{~kg} \cdot \mathrm{m}^{-1}$ width of sod, there was a greater than $50 \%$ to $99 \%$ chance of obtaining the producer-preferred sod strength rating (Fig. 1; Table 2). These values fall within previously reported acceptable sod strength ranges of at least 49 to $67 \mathrm{~kg} \cdot \mathrm{m}^{-1}$ (based on at least $20 \mathrm{~kg}$ shear for sod widths of 30 to $41 \mathrm{~cm}$ cut to a thickness of $19 \pm 6 \mathrm{~mm}$; Hall et al., 1985), $73 \mathrm{~kg} \cdot \mathrm{m}^{-1}$ (based on at least $22 \mathrm{~kg}$ shear for sod widths of $30 \mathrm{~cm}$ cut to a thickness of $12 \mathrm{~mm}$; Shearman et al., 2001), and $97 \mathrm{~kg} \cdot \mathrm{m}^{-1}$ (based

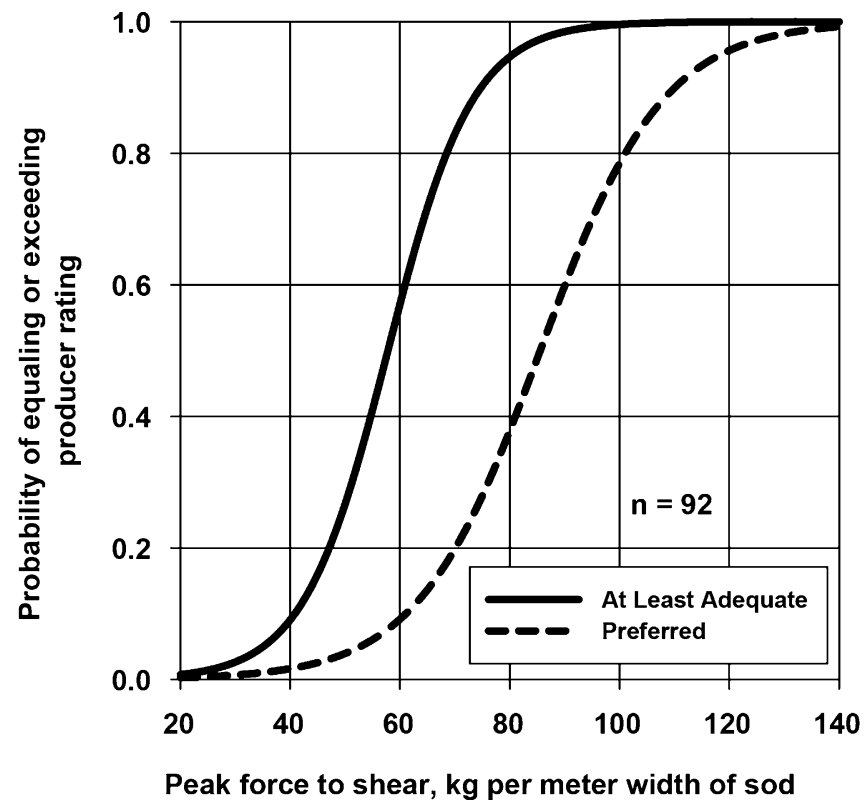

Fig. 1. Probability curves of obtaining a producer rating of at least "Acceptable" (includes "Acceptable" and "Preferred" categories) and 'Preferred' only sod strength in relation to peak shear force (kilograms per meter width of sod cut to a thickness of 10 to $20 \mathrm{~mm}$ ) for predominately kentucky bluegrass sod grown across 3 years (2010-12) in West Kingston, RI. The single datum for the "Unacceptable-Too Mature" category was not included in either logistic regression.

Table 1. Frequency of observations between producer subjective sod strength ratings and peak shear force categories (kilograms per meter width of sod) across 3 years (2010-12) for predominately kentucky bluegrass (Poa pratensis L.) turf sod in West Kingston, RI ( $\mathrm{n}=93)$.

\begin{tabular}{lccccccc}
\hline & \multicolumn{5}{c}{ Peak force to shear $\left(\mathrm{kg} \cdot \mathrm{m}^{-1}\right)$ category } \\
\cline { 2 - 7 } Producer rating & 40 to $<55$ & 55 to $<70$ & 70 to $<85$ & 85 to $<100$ & 100 to $<115$ & 115 to $<140 \geq 140$ \\
\hline Unacceptable-Too Weak & 10 & 8 & 3 & 0 & 0 & 0 & 0 \\
Adequate & 2 & 14 & 12 & 7 & 2 & 0 & 0 \\
Preferred & 0 & 3 & 9 & 9 & 8 & 5 & 0 \\
Unacceptable-Too Mature & 0 & 0 & 0 & 0 & 0 & 0 & 1 \\
$\chi^{2}$ test & & $d f$ & $\chi^{2}$ value & $P$ value & & \\
Cochran-Mantel-Haenszel & & 1 & 44.49 & $<0.0001$ & & \\
Log likelihood ratio & 18 & 71.49 & $<0.0001$ & \\
\hline
\end{tabular}


Table 2. Logistic regression coefficients for binary response of at least "Adequate" (includes Adequate and Preferred categories) versus unacceptable, and "Preferred" versus not preferred producer assessments of sod strength in relation to quantitative peak shear force measurements with associated measures of peak shear force per meter width of sod at selected probabilities across 3 years $(2010-12)(\mathrm{n}=92)$ for predominately kentucky bluegrass (Poa pratensis L.) turf in West Kingston, RI. The single datum for "Unacceptable-Too Mature" was excluded from the analyses.

\begin{tabular}{|c|c|c|c|c|c|c|c|}
\hline \multicolumn{4}{|c|}{ At least Adequate } & \multicolumn{4}{|c|}{ Preferred } \\
\hline Intercept & Slope & Maximum rescaled $r^{2}$ & $P$ value & Intercept & Slope & Maximum rescaled $r^{2}$ & $P$ value \\
\hline & Probability & Peakshear force $\left(\mathrm{kg} \cdot \mathrm{m}^{-1}\right)$ & & & Probability & Peak shear force $\left(\mathrm{kg} \cdot \mathrm{m}^{-1}\right)$ & \\
\hline & 0.60 & 61 & & & 0.60 & 90 & \\
\hline & 0.65 & 63 & & & 0.65 & 92 & \\
\hline & 0.70 & 64 & & & 0.70 & 95 & \\
\hline & 0.85 & 71 & & & 0.85 & 105 & \\
\hline & 0.90 & 75 & & & 0.90 & 110 & \\
\hline & 0.95 & 81 & & & 0.95 & 118 & \\
\hline & 0.97 & 85 & & & 0.99 & 140 & \\
\hline & 1.00 & 140 & & & & & \\
\hline
\end{tabular}

on $44.5 \mathrm{~kg}$ shear for sod widths of $46 \mathrm{~cm}$ cut to a thickness of 19 to $25 \mathrm{~mm}$; Petrovic, 2008).

Although we found that a peak shear force between 70 and $140 \mathrm{~kg} \cdot \mathrm{m}^{-1}$ width of sod resulted in a preferred sod strength, there is uncertainty about the upper boundary before strength becomes unacceptable because of being overly mature, and sod quality declines. We did record a peak shear force measurement of $221 \mathrm{~kg} \cdot \mathrm{m}^{-1}$ width of sod on a 2-year-old predominately kentucky bluegrass stand in 2010 that was rated as unacceptable by the producer because of being overly mature with excessive thatch. However, we only had one observation at this level of peak shear force and turf maturity. Presumably then, unacceptably high sod strength for kentucky bluegrass might be reached somewhere between 140 and $221 \mathrm{~kg} \cdot \mathrm{m}^{-1}$ width of sod at the thickness of the sod harvested in these studies (10 to $20 \mathrm{~mm}$ ).

Previous reports have documented how cultural practices can affect sod strength. Cool- and warm-season turfgrass genotypes, species, cultivars, blends, and mixtures result in different sod strength measurements (Giese et al., 1997; Goatley et al., 1997; Hall et al., 1985; Hurley and Skogley, 1975; Rieke and Beard, 1969; Taylor and Schmidt, 1980), and these should influence the selection of grasses for sod production. In general, higher rates of $\mathrm{N}$ are associated with lower sod strength measurements than those obtained at lower $\mathrm{N}$ rates (Hall, 1980; Li et al., 2011; Rieke and Beard, 1969; Ruemmele et al., 2001). This suggests that sod strength-testing devices should be able to provide guidance for $\mathrm{N}$ fertilization that result in more consistent sod quality than guidance following subjective methods. Growth regulators have little negative effects on sod strength (Hall and Bingham, 1993), or can result in enhanced sod strength (McCalla et al., 2008). Lower rates of pyridine herbicides generally resulted in greater sod strength than those herbicides at higher rates (Goatley et al., 1997), whereas mowing height did not affect sod strength (Hall, 1980).
Although these studies have been useful in separating out sod strength differences between and among selected cultural practices, it is uncertain as to how these values would be useful to the producer. The results may suggest specific practices to the producer, but they lack guidance as to whether the outcomes of these practices would result in acceptable to optimum sod strength.

We report ranges of quantitative sodstrength measurements that would correspond to subjective producer assessments of strength with high probabilities of concordance. By defining these benchmarks, the results from the device we used to quantitatively measure predominately kentucky bluegrass sod strength can be put into a useable context for a sod producer, and may encourage the use of sod-strength testing devices as a routine procedure. The quantitative measurement of sod strength would also benefit the sod producer and buyers of sod by setting standards or providing strength criteria and specifications for contracts, or to resolve contract conflicts where sod strength is disputed between sellers and buyers or users.

Since perception of sod strength is subjective, we can never quantify an exact peak force value that perfectly matches acceptable or preferred assessments. This can be seen by the overlapping of the high-end peak force values for "Adequate" and the low-end peak force values for "Preferred" (Table 1). However, probability curves can be generated that indicate the chances that specific peak shear force measurements will correspond to subjective assessment of unacceptable, acceptable, or preferred sod strength at harvest, as shown in Fig. 1.

We acknowledge the limitation of only four different subjective evaluators across the three years in our study. However, these were experienced sod producers (10 to more than 20 years of experience with sod) and it is likely that they were able to judge reasonably well when sod had sufficient tensile strength for harvesting and handling. Even with this limitation in the number of evaluators, our data give initial benchmark quantitative values by which to delineate kentucky blue- grass sod-strength categories for future research or to initiate producer use of these values with the expectation that they could change as more data are collected. With a larger pool of subjective evaluators, the range of peak shear force values may shift slightly for each category, but this would need to be validated with more research in this area. We also suspect that our delineation of categories will change with differences in the thickness of sod cutting depth and with different species, especially for warm-season turfgrass sods. Sod thickness ranged from 10 to $20 \mathrm{~mm}$ in our study, and it is likely that greater sod thickness will require greater peak shear strength to separate a sod sample. Therefore, suggested optimum peak shear strength values will have to take into account cutting thickness.

Although experienced sod producers may be good at subjectively judging sod strength, we believe that the use of a quantitative sod strength measurement, as an objective method to guide management practices, may result in more consistent sod quality and better guidance for management practices for optimum sod strength than subjective assessment. We suggest that the quantitative testing of sod strength could be used in different ways: 1 ) as a postharvest test to provide an assessment of management practices on sod strength that occurred before sod harvest, 2) as an in-season test to monitor sod strength on selected strips throughout the growing season to assist in management decisions at critical phases during sod growth and development, 3) to help determine when sod can be harvested as early as possible with acceptable sod strength, and or 4) to develop a set of standards or specifications used by the sod industry, university extension system, agronomic consultants, or governmental agencies in achieving best management practices or target specifications of sod strength for contracts.

\section{Literature Cited}

Agnew, M.L. and N.E. Christians. 1992. Sod reestablishment of five Kentucky bluegrass cultivars. J. Prod. Agr. 5:50-52. 
Burns, R.E. and J.G. Futral. 1980. Measuring sod strength with an Instron universal testing instrument. Agron. J. 72:571-573.

Cutulle, M.A., J.F. Derr, D. McCall, B. Horvath, and A.D. Nichols. 2013. Impact of hybrid bluegrass and tall fescue seeding combinations on brown patch severity and weed encroachment. HortScience 48:493-500.

Giese, M.S., R.E. Gaussoin, R.C. Shearman, and T.P. Riordan. 1997. Sod production characteristics of turf-type Buchloë dactyloides. Intl. Turfgrass Soc. Res. J. 8:455-465.

Goatley, Jr., J.M., D.B. Smith, P.D. Gerard, and G.E. Coats. 1997. Comparing sod strength parameters of warm-season turfgrasses using a hydraulically driven sod strength machine. HortTechology 7:421-426.

Hall, III, J.R. 1980. Effect of cultural factors on tall fescue-Kentucky bluegrass sod quality and botanical composition. In: J.B. Beard (ed.) Proc. 3rd Intl. Turfgrass Res. Conf., Munich, West Germany. 11-13 July 1977. ASA, CSSA, SSSA, Madison, WI. p. 367-377.

Hall, III, J.R., and S.W. Bingham. 1993. Impact of growth regulators on Kentucky bluegrass sod management and installation parameters. Intl. Turfgrass Soc. Res. J. 7:701-707.

Hall, III, J.R., L.H. Taylor, and J.F. Shoulders. 1985. Sod strength and turfgrass quality of Kentucky bluegrass cultivars, blends and mixtures. In: F Lemaire (ed.). Proc. 5th Intl. Turfgrass Res. Conf., Avignon, France. 1-5 July 1985. INRA, Paris. p. 807-820.

Hurley, R.H. and C.R. Skogley. 1975. Evaluation of Kentucky bluegrass and red fescue cultivars for sod production. Agron. J. 67:79-82.

Li, D.Y., W.J. Fang, and L.B. Han. 2011. Nitrogen fertilization influences shear strength and quality of Kentucky bluegrass sod grown on clay. Agron. J. 103:751-755

McCalla, J., Jr., M. Richardson, D. Karcher, J. Landreth, and A. Patton. 2008. Sod production utilizing an improved seeded bermudagrass cultivar. Online. Appl. Turfgrass Sci. doi:10.1094/ ATS-2008-0118-01-RS.

Parish, R.L. 1995. A simple device to measure sod strength. HortTechnology 5:308-309.

Petrovic, M. 2008. Reducing nitrogen groundwater contamination from sod production on Long Island, NY. CUTT, Cornell University Turfgrass Times. 3:8-10, 12.

Rieke, P.E. and J.B. Beard. 1969. Factors in sod production of Kentucky bluegrass. In: Proc. 1st Intl. Turfgrass Res. Conf., Harrogate, UK. 1518 July 1969. Sports Turf Res. Inst., Bingley, Yorkshire, UK. p. 514-520.

Rieke, P.E., J.B. Beard, and C.M. Hansen. 1968. A technique to measure sod strength for use in sod production studies, p. 60. In: 1968 Agronomy abstracts. ASA-CSSA-SSSA, Madison, WI.

Ruemmele, B.A., M.C. Engelke, R.H. White, and V. Lehman. 2001. Alternate sod production method for zoysiagrass. Intl. Turfgrass Soc. Res. J. 9:910-916.

Sharpe, S.S., R. Dickens, and D.L. Turner. 1989. Herbicide effects on tensile strength and rooting of bermudagrass (Cynodon dactylon) sod. Weed Technol. 3:353-357.

Shearman, R.C., T.R. Turner, K.N. Morris, R.E Gaussoin, M.R. Vaitkus, and L.A. Wit. 2001. Sod strength and lateral spread of Poa pratensis cultivars and experimental lines. Intl. Turfgrass Soc. Res. J. 9:928-933.

Shildrick, J.P. 1982. Mixtures and seed rates for sod production. J. Sports Turf Res. Inst. 58:76-95.

Sorochan, J.C. and J.N. Rogers, III. 2000. Measuring sod strength of Kentucky bluegrass and supine bluegrass. TurfGrass Trends, July, p. 6-9.

Taylor, L.H. and R.E. Schmidt. 1980. Differences in sod strength, rooting, and turfgrass quality of Kentucky bluegrass cultivars resulting from seasonal and environmental conditions. In: J.B. Beard (ed.). Proc. 3rd Intl. Turfgrass Res. Conf., Munich, West Germany. 11-13 July 1977. ASA, CSSA, and SSSA, Madison, WI p. $31-38$. 